\title{
A tale of two cords
}

\author{
Vishnu VY, Praveen Kesav, Sahil Mehta, Sudesh Kumar Prabhakar
}

Department of Neurology, Post Graduate Institute of Medical Education and Research (PGIMER), Chandigarh, India

\section{Correspondence to} Sudesh Kumar Prabhakar, sudeshprabhakar@gmail.com

\section{DESCRIPTION}

A 24-year-old lady, recently married, was brought to our hospital by her husband when he incidentally noticed a tuft of hair in her lower back which he considered as a bad omen after consulting a rural Indian faith healer. On physical examination, she had a tuft of hair in her lower back which was present since birth and progressively increasing in size (figure 1A). Rest of the physical examination was normal with no neurological deficits noted. MRI of the spine revealed a low lying spinal cord that was split into two unequal hemicords by a bony spur extending from lower border of L3 to upper border of L5 vertebral body (figures 2A,B). The conus medullaris reached up to L4-5 vertebral level with thick filum terminale. A large syrinx was present in distal spinal cord (left hemicord) extending from L1 to L4 vertebral level (figure 2C). This was associated with closed spina bifida and dural ectasia in the lower lumbar region, without meningocele or meningomyelocele. Diastematomyelia is a rare spinal dysraphism, characterised by a split spinal cord, caused by bony, cartilaginous or fibrous septa producing complete or incomplete hemicords. Clinical presentation is usually in childhood, with lower thoracic or upper lumbar spine involvement. ${ }^{1}$ Clinical suspicion is prompted by scoliosis, skin markers and neurological deficits. In adults, neurological deficits are an indication for surgery and prophylactic spur removal is not recommended in asymptomatic adults. $^{2}$ Our patient, being asymptomatic was reassured and advised regular follow-up.

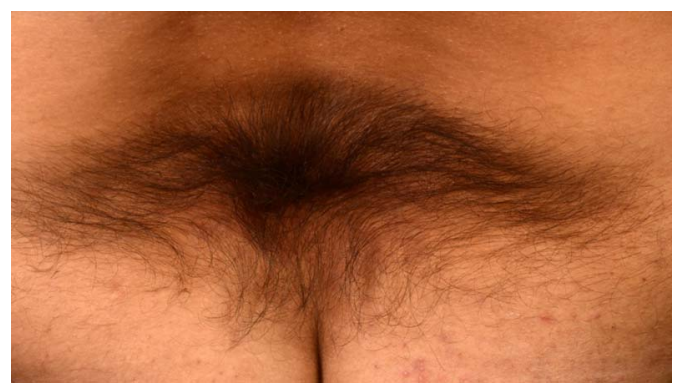

Figure 1 Clinical photograph revealing midline tuft of hair in the lower back.

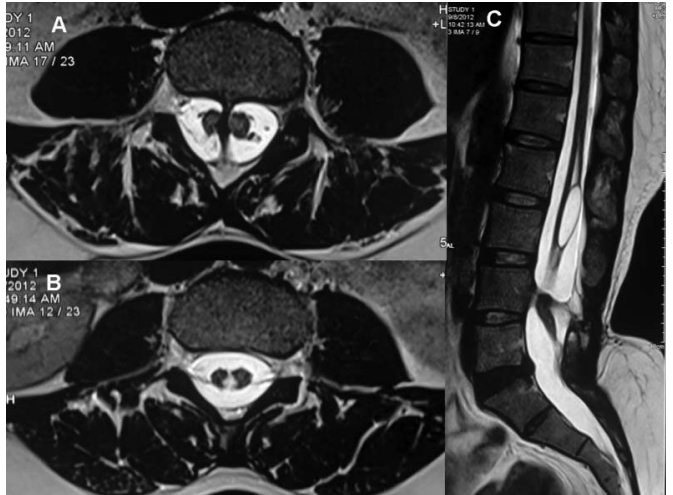

Figure $2 \mathrm{MRI}$ of lumbosacral spine revealing a low lying split cord with bony spur (L3-5) on axial T2-weighted sequence ( $A$ and $B$ ) and a large syrinx extending from L1 to L4 vertebral level on T2 sagittal sequence $(\mathrm{C})$.

\section{Learning points}

A thorough general physical examination is indispensable in not only arriving at an accurate neurological diagnosis many a time, but also to demystify the stigma associated with cutaneous manifestations of spinal dysraphism in the minds of care givers, as exemplified in our case.

- Marked clinicoradiological dissociation is well known with spinal dysraphisms, as seen in our case.

- Reassurance is the only treatment modality to be employed for diastematomyelia without neurological symptoms/signs.

Competing interests None.

Patient consent Obtained.

Provenance and peer review Not commissioned; externally peer reviewed.

\section{REFERENCES}

1 Prasad VS, Sengar RL, Sahu BP, et al. Diastematomyelia in adults: modern imaging and operative treatment. Clin Imaging 1995;19:270-4.

2 Linn RM, Ford LT. Adult diastematomyelia. Spine 1994;19:852-4.
To cite: VY V, Kesav $P$, Mehta S, et al. BMJ Case Rep Published online: [please include Day Month Yearl doi:10.1136/bcr-2013008862 


\section{Images in...}

Copyright 2013 BMJ Publishing Group. All rights reserved. For permission to reuse any of this content visit http://group.bmj.com/group/rights-licensing/permissions.

BMJ Case Report Fellows may re-use this article for personal use and teaching without any further permission.

Become a Fellow of BMJ Case Reports today and you can:

- Submit as many cases as you like

- Enjoy fast sympathetic peer review and rapid publication of accepted articles

- Access all the published articles

- Re-use any of the published material for personal use and teaching without further permission

For information on Institutional Fellowships contact consortiasales@bmjgroup.com

Visit casereports.bmj.com for more articles like this and to become a Fellow 